\title{
EDITORIAL
}

\section{FRAILTY: DIAGNOSIS AND MANAGEMENT}

\author{
J.E. MORLEY
}

Division of Geriatric Medicine, Saint Louis University School of Medicine, 1402 S. Grand Blvd., M238, St. Louis, MO 63104, Email: morley@slu.edu

Frailty is a common condition occurring in approximately 1 in 20 persons over 60 years of age (1). Frailty is a condition in which a functional older person is at increased risk of developing either disability or dying when exposed to physical or psychological stressors (2-5). A frail person has decreased reserve and diminished resistance due to an accumulation of multiple deficits which can be social, psychological or physiological (6-9). The attempt of operationalizing this definition has led to a number of variable definitions of frailty. For a definition to be meaningful it should correlate at baseline with self-rated health, be more common in females than males and tend to increase with advancing age. The criterion for a successful definition needs to be that it predicts an adverse outcome such as mortality, hospitalization, institutionalization, loss of basic activities of daily living, and decline in social interaction or injurious falls $(10,11)$. The definition should not have to rely on the presence in the population of a subpopulation who can be identified by already having a deficit in basic activities of daily living. Finally while a person may be frail because of a single disease, eg, end stage heart failure or chronic obstructive pulmonary disease, the definition should not be disease driven (Figure 1).

Figure 1

The Frailty Cascade

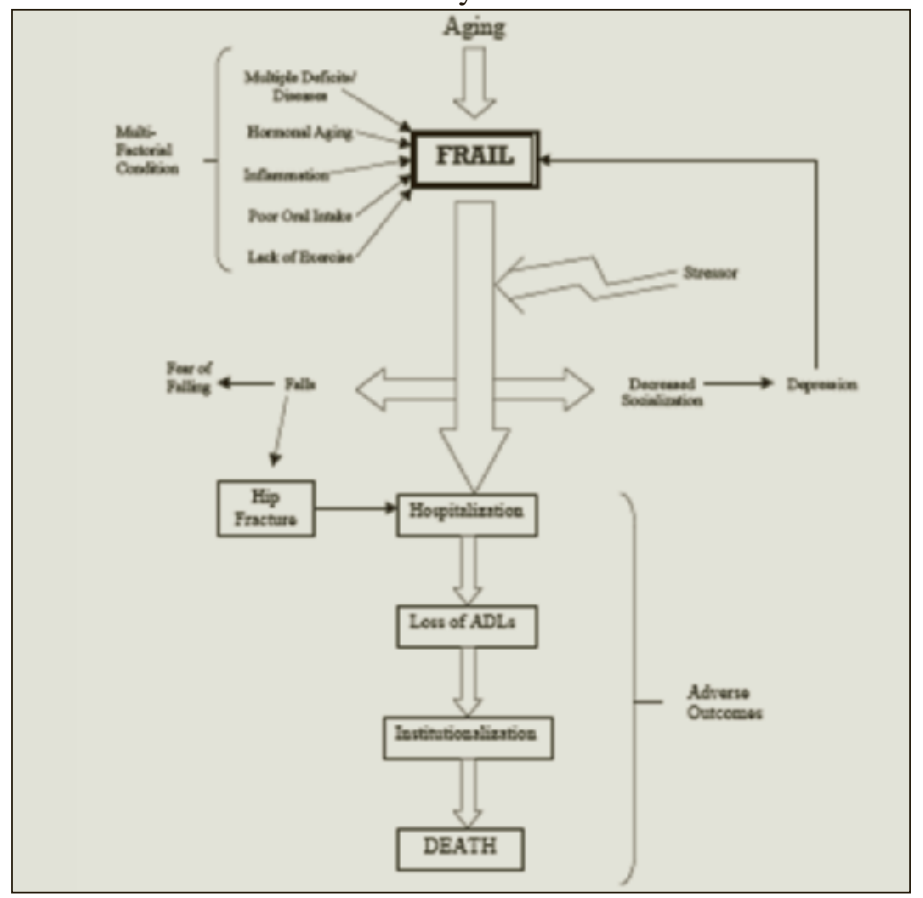

At present, three different domains have been used to construct frailty models. These are functional, deficit accumulation (burden) and biological/physiological models. The functional domain model used deficiencies in four areas of functioning (physical, nutrition, cognition and sensory) and was developed in the Alameda County Study (12) Rockwood and colleagues $(13,14)$ developed a frailty index that measures the cumulative burden of deficits including symptoms, diseases, conditions and disability. It was developed in the Canadian Study of Health and Aging (15). Fried et al (16) developed the biological model based on five criteria namely weight loss, exhaustion, low energy expenditure, slowness (walking time) and weakness (grip strength). The Study of Osteoporotic Fractures developed a biological model based on weight loss, fatigue and power (arising from a chair 5 times) (17). The SHARE-Frailty Index is similar to the Fried model and includes grip strength (18). The individual models show poor identification of the same groups of people being frail with the concordance ranging from 25 to $40 \%$ (19). Psychosocial models of frailty (eg, dementia, depression, poverty, problematic environment) will not be considered in this editorial $(20,21)$.

None of the above models are currently suitable for widespread clinical application. For this reason, the International Association of Nutrition and Aging (IANA) developed the FRAIL scale $(22,23)$. $F$ is for fatigue, $R$ is for resistance (climbing one flight of stairs), A is for aerobic (walk one block), $\mathrm{I}$ is for illnesses ( 5 or more) and $\mathrm{L}$ is for loss of weight ( $>5 \%$ in last year). One or two positive is prefrail and 3 or more is frail. This scale has been validated with and without the inclusion of ADLs (24 and Morley, Malmstrom and Miller unpublished). The scale overlaps with the biological, the burden and the functional scales. Its advantage is it can be very quickly administered as it is a set of simple questions. It would appear that the FRAIL Index is the clinical instrument of choice.

\section{Pathophysiology}

A key in the development of frailty is the anorexia of aging and the associated weight loss, particularly when illness is superimposed $(25,26)$. The prevalence of protein energy malnutrition in older persons is common (27-33). Both gait speed and functional status have been associated with malnutrition $(34,35)$. This has led to the question of whether the Mini Nutritional assessment could be an appropriate tool to measure frailty in older persons (36). Most persons with 
cachexia will also have associated frailty $(37,38)$. This may be associated not only with the increase in malnutrition, but also with the cytokine excess seen in persons with cachexia $(39,40)$.

The loss of muscle mass, strength and power classically seen in frailty is closely associated with the development of sarcopenia (41-46). Sarcopenia leads to mobility loss and a decrease in gait speed. The development of sarcopenia closely parallels the decline in testosterone that occurs in age $(47,48)$. Frailty is correlated with declining testosterone levels in some but not all studies $(24,49-51)$. In frail older women multiple anabolic hormonal deficiencies are present in frail older women (52). Other major factors include poor protein intake $(53,54)$, cytokine excess (55) and decreased motor endplates (56).

Other factors associated with frailty include anemia (57), depression $(58,59)$ and cognitive decline $(60-62)$. All of these can lead to fatigue, decreased food intake and decreased physical activity. Vitamin B12 deficiency has also been associated with frailty $(63,64)$.

\section{Management}

The FRAIL index should be given to all persons over 60 years of age being seen by a physician. Clearly the first step in managing frailty is exercise. Fiatarone et al (65) originally demonstrated the utility of resistance exercise in managing frailty. A meta-analysis has demonstrated that exercise improves outcomes in frail older persons (66). Exercise has been shown to also be beneficial in delaying functional deterioration in nursing homes (67).

An adequate caloric and protein intake represents a cornerstone of managing frailty (68). A high leucine balanced amino acid supplement is recommended for optimal outcomes $(69,70)$. Supplements should be given between meals $(71)$. Between 1.2 to $1.5 \mathrm{~g}$ of protein per kilogram body mass is the recommended daily protein intake. Low $25(\mathrm{OH})$ vitamin D is commonly associated with frailty and sarcopenia (72-76). Vitamin D at 1000 IU daily is a minimal replacement dose (7781). If $25(\mathrm{OH})$ vitamin $\mathrm{D}$ levels are obtained, the replacement dose should aim at circulating levels of $70 \mathrm{nmol}$.

Three studies in frail elderly have shown that testosterone tends to increase muscle mass and power (82-84). More impressive effects have been seen in persons with end stage cardiac failure (85-87). While one study suggested testosterone increased cardiovascular disease this was predominantly due to increased pedal edema. Edema is common in frail older persons and associated with heart disease. In frail persons, the increase in water retention would be expected to increase edema. In these studies there have been more deaths in the placebo compared to the treatment group. A single study in assisted living found that testosterone with a caloric supplement decreased hospitalizations (88).

Dehydroepiandrosterone (DHEA) levels decrease with aging and have, in cross-sectional studies, been associated with declining function (89). Most studies of DHEA in humans have produced minimal positive results. Kenny et al (90) did find that DHEA combined with exercise improved muscle strength and physical function in frail older females.

A number of selective androgen receptor molecules (SARMs) are under development. These may be particularly useful in the management of frailty. Whether or not this is the case awaits the outcome of appropriately designed and powered clinical trials (91).

Frailty and falls are strongly related to anemia (91-93). However, there are no studies showing that correction of anemia improves outcomes in frail persons. Certainly all frail persons should have the causes of the anemia carefully assessed for treatable causes. The use of erythropoietin to treat anemia of chronic disease is problematic but most probably reasonable when the hemoglobin is less than $10 \mathrm{~g} / \mathrm{dl}(94,95)$. Development of therapeutic antibodies to hepcidin are enthusiastically awaited. Meanwhile a small study in Castleman syndrome showed improvement in anemia with the use of an interleukin-6 antibody (96).

Geriatric evaluation and management programs have been shown to be successful in improving outcomes in persons with poor function (97). However, a study aimed specifically at using comprehensive geriatric assessment in 310 pre-frail and frail older persons failed to improve the Barthel Index though the changes were in the expected direction (98). Three other studies did show positive interventions of comprehensive geriatric assessment programs (99-101). A focus on correcting orthostasis where present appears to be a clear area for improvement $(102,103)$. Care should also be undertaken to reduce polypharmacy where possible (104-106). Aggressive referral for physical therapy including for limitations in dual tasking $(107,108)$.

Table 1 lists the appropriate treatments whose need should be evaluated and carried out where indicated.

Table 1

Appropriate Management for Frailty

A. Administer FRAIL Index:
Fatigue
Resistance (walk up on flight of stairs)
Aerobic (walk one block)
Illness (5 or greater)
Loss of weight ( $>5 \%$ in one year)
(1 or 2 = prefail; 3 or more $=$ frail)
Treatments for all frail
1. Exercise therapy including:
$\quad$ a. $\quad$ Aerobic
$\quad$ b. $\quad$ Resistance
$\quad$ d. $\quad$ Balance
2. High protein diet (1.2-1.5g/kg)
3. Leucine enriched essential amino acids supplement between meals
4. Vitamin D 1000 IU daily
Focused treatment
1. Testosterone in males with low testosterone levels
2. Treat anemia - treatable causes and erythropoietin if Hb< $10 \mathrm{~g} / \mathrm{dl}$
3. Treat Depression
4. Reduce polypharmacy




\section{JNHA: FRAILTY AND COGNITIVE DECLINE}

\section{References}

1. Wilhelm-Leen ER, Hall YN, K Tamura M, Chertow GM. Frailty and chronic kidney disease: The Third National Health and Nutrition Evaluation Survey. Am J Med 2009;122:664-71.

2. Gobbens RJ, Luijkx KG, Wijnen-Sponselee MT, Schols JM. Towards an integral conceptual model of frailty. J Nutr Health Aging 2010;14:175-81.

3. Morley JE, Perry HM 3rd, Miller DK. Editorial: Something about frailty. J Gerontol A Biol Sci Med Sci 2002;57:M698-704.

4. Conroy S. Defining frailty - the Holy Grail of geriatric medicine. J Nutr Health Aging 2009;13:389.

5. Gobbens RJ, Luijkx KG, Wijnen-Sponselee MT, Schols JM. In search of an integral conceptual definition of frailty: opinions of experts. J Am Med Dir Assoc 2010;11:338-43.

6. Pel-Little RE, Schuurmans MJ, Emmelot-Vonk MH, Verhaar HJ. Frailty: Defining and measuring of a concept. J Nutr Health Aging 2009;13:390-4.

7. Gobbens RJ, van Assen MA, Luijkx KG, et al. Determinants of frailty. J Am Med Dir Assoc 2010;11:356-64.

8. Rockwood K, Abeysundera MJ, Mitnitski A. How should we grade frailty in nursing home patients? J Am Med Dir Assoc 2007;8:595-603.

9. Morley JE. Anorexia, weight loss, and frailty. J Am Med Dir Assoc 2010;11:225-8

10. Rockwood K. What would make a definition of frailty successful? Age Ageing 2005;34:432-4

11. Decullier E, Couris CM, beauchet O, et al. Falls and fallers' profiles. J Nutr Health Aging 2010;14:602-8.

12. Strawbridge WJ, Shema SJ, Balfour JL et al. Antecedents of frailty over three decades in an older cohort. J Gerontol B Psychol Sci Soc Sci 1998;53:S9-S16.

13. Rockwood K, Andrew M, Mitnitski A. A comparison of two approaches to measuring frailty in elderly people. J Gerontol A Biol Sci Med Sci 2007;62A:738743.

14. Lucicesare A, Hubbard RE, Fallah N, et al. Comparison of two frailty measures in the Conselice Study of Brain Ageing. J Nutr Health Aging 2010;14:278-81.

15. Canadian Study of Health and Aging: Study methods and prevalence of dementia. Can Med Assoc J 1994;150:899-913.

16. Fried LP, Tangen Cm, Walston J, et al. Untangling the concepts of disability, frailty, and comorbidity: Implications for improved targeting an area. J Gerontol A Biol Sci Med Sci 2004;59A:255-263.

17. Ensrud KE, Ewing SK, Taylor BC, Fink HA, Stone KL, Cauley JA, Tracy JK, Hochberg MC, Rodondi N, Cawthon PM: For the Study of Osteoporotic Fractures Research Group. J Gerontol A Biol Sci Med Sci 2007;62:744-51.

18. Romero-Ortuno R, Walsh CD, Lawlor BA, Kenny RA. A frailty instrument for primary care: Findings from the Survey of Health, Ageing and Retirement in Europe (SHARE). BMC Geriatr 2010;10:57

19. Cigolle CT, Ofstedal MB, Tian Z, Blaum CS. Comparing models of frailty: The health and retirement study. JAGS 2009;57:830-839.

20. Boyle PA, Buchman AS, Wilson RS, et al. Physical frailty is associated with incident mild cognitive impairment in community-based older persons. J Am Geriatr Soc 2010;58:248-55.

21. Rafi MA, Al Snih S, Ostir GV, et al. Cognitive status and future risk of frailty in older Mexican Americans. J Gerontol A Biol Sci Med Sci 2010;65:1228-34.

22. Abellan van Kan G. Rolland Y, Bergman H, et al. The I.A.N.A. Task Force on frailty assessment of older people in clinical practice. J Nutr Health Aging 2008;12:29-37.

23. Abellan van Kan G, Rolland YM, Morley JE, Vellas B. Frailty: toward a clinical definition. J Am Med Dir Assoc 2008;9:71-72.

24. Hyde Z, Flicker L, Almeida OP, Hankey GJ, McCaul KA, Chubb SA, Yeap BB Low free testosterone predicts frailty in older men: The Health in Men Study. J Clin Endocrinol Metab 2010;95:3165-72.

25. Morley JE. Weight loss in older persons: New therapeutic approaches. Curr Pharm Des 2007;13:3637-47.

26. Morley JE. Clinical practice in nursing homes as a key for progress. J Nutr Health Aging 2010;14:586-93.

27. Johansson L, Sidenvall B, Lalmberg B, Christensson L. Who will become malnourished? A prospective study of actors associated with malnutrition in older persons living at home. J Nutr Health Aging 2009;13:855-61.

28. Mirarefin M, Sharifi F, Fakhrzadeh H, et al. Predicting the value of the Mini Nutritional Assessment (MNA) as an indicator of functional ability in older Iranian adults (Kahrizak elderly study). J Nutr Health Aging 2011;15:175-80.

29. Sancario D, D'Onofrio G, Franceschi M, et al. Validation of a ModifiedMultidimensional Prognostic Index (m-MPI) including the Mini Nutritional Assessment Short-Form (MNA-SF) for the prediction of one-year mortality in hospitalized elderly patients. J Nutr Health Aging 2011;15:169-73.

30. Kaiser MJ, Bauer JM, Ramsch C, et al; MNA-International Group. Validation of the Mini Nutritional Assessment short-form (MNA-SF): a practical tool for identification of nutritional status. J Nutr Health Aging 2009;13:782-8.

31. Morley JE. Assessment of malnutrition in older persons: A focus on the Mini Nutritional Assessment. J Nutr Health Aging 2011;15:87-90.

32. Volkert D, Saeglitz C, Gueldenzoph H, et al. Undiagnosed malnutrition and nutrition- related problems in geriatric patients. J Nutr Health Aging 2010;14:387-92.

33. St-Arnaud McKenzi D, Kergoat MJ, Dube L, Ferland G. The evolution of nutritional status of geriatric patients without cachexia is associated with food intake in subacute care. J Nutr Health Aging 2009;13:83-8.

34. Chevalier S, Saoud F, Gray-Donald K, Morais JA. The physical functional capacity of frail elderly persons undergoing ambulatory rehabilitation is related to their nutritional status. J Nutr Health Aging 2008;12:721-6.

35. Abellen van Kan G,. Rolland Y, Andrieu S, et al. Gait speed at usual pace as a predictor of adverse outcomes in community-dwelling older people an International Academy on Nutrition and Aging (IANA) Task Force. J Nutr Health Aging 2009:13:881-9.

36. Abellan van Kan G, Vellas B. Is the Mini Nutritional Assessment an appropriate tool to assess frailty in older adults? J Nutr Health Aging 2011;15:159-61.

37. Argiles JM, Anker SD, Evans WJ, et al. Consensus on cachexia definitions. J Am Med Dir Assoc 2010;11:229-30.

38. Morley JE, Anker SD, Evans WJ. Cachexia and aging: an update based on the Fourth International Cachexia Meeting. J Nutr Health Aging 2009;13:47-55.

39. Yeh SS, Lovitt S, Schuster MW. Usage of megestrol acetate in the treatment of anorexia-cachexia syndrome in the elderly. J Nutr Health Aging 2009;13:448-54.

40. Haren MT, Malmstrom TK, Miller DK, Patrick P, Perry HM 3rd, Herning MM, Banks WA, Morley JE. Higher C-reactive protein and soluble tumor necrosis factor receptor levels are associated with poor physical function and disability: A crosssectional analysis of a cohort of late middle-aged African Americans. J Gerontol A Biol Sci Med Sci 2010;65:274-81

41. Rolland Y, Czerwinski S, Abellan van Kan G, et al. Sarcopenia: its assessment, etiology, pathogenesis, consequences and future perspectives. J Nutr Health Aging 2008; 12:433-50.

42. Abellan van Kan G. Epidemiology and consequences of sarcopenia. J Nutr Health Aging 2009;13:708-12.

43. Bauer JM, Kaiser MJ, Sieber CC. Sarcopenia in nursing home residents. J Am Med Dir Assoc 2008;9:545-51.

44. Abellan van Kan G, Andre E, Bischoff Ferrari HA, et al. Carla Task Force on Sarcopenia: Propositions for clinical trials. J Nutr Health Aging 2009;13:700-7.

45. Fielding RA, Vellas B, Evans WJ, et al. Sarcopenia: an undiagnosed condition in older adults. Current consensus definition: prevalence, etiology, and consequences. J Am Med Dir Assoc 2011;12:249-56.

46. Morley JE, Abbatecola AM, Argiles JM, et al; The Society on Sarcopenia, Cachexia and Wasting Disorders Trialist Workshop. Sarcopenia with limited mobility: an international consensus. J Am Med Dir Assoc 2011;12:403-409.

47. Wang C, Nieschlag E, Swerdloff R, Behre HM, Hellstrom WJ, Gooren LJ, Kaufman JM, Legros JJ, Lunenfeld B, Morales A, Morley JE, Schulman C, Thompson IM, Weidner $\mathrm{W}, \mathrm{Wu} F C$. Investigation, treatment and monitoring of late-onset hypogonadism in males: ISA, ISSAM, EAU, EAA and ASA recommendation. Eur J Endocrinol 2008;159:507-14.

48. Morley JE. Anabolic steroids and frailty. J Am Med Dir Assoc 2010;112:533-6.

49. Tajar A, O'Connell MD, Mitnitski AB, et al. Frailty in relation to variations in hormone levels of the hypothalamic-pituitary-testicular axis in older men: results from the European male aging study. J Am Geriatr Soc 2011;59:814-21.

50. Travison TG, Shackelton R, Araujo AB, Morley JE, Williams RE, Clark RV, McKinlay. Frailty, serum androgens, and the CAG repeat polymorphism: Results from the Massachusetts Male Aging Study. J Clin Endocrinol Metab 2010;95:274654.

51. Travison TG, Nguyen AH, Naganthan V, Stanaway FF, Blyth FM, Cumming RG, LeCouteur DG, Sambrook PN, Handelsman DJ. Changes in reproductive hormone concentrations predict the prevalence and progression of the frailty syndrome in older men: The Concord Health and Ageing in Men Project. J Clin Endocrinol Metab 2011, Jun 15 \{Epub ahead of print

52. Varadhan R, Chaves PH, Lipsitz LA, et al. Frailty and impaired cardiac autonomic control: new insights from principal components aggregation of traditional heart rate. J Gerontol A Biol Sci Med Sci 2009;64:682-7.

53. Zoltick ES, Sahni S, McLean RR, et al. Dietary protein intake and subsequent falls in older men and women: The Framingham Study. J Nutr Health Aging 2011;15:14752.

54. Beasley JM, LaCroix AZ, Neuhouser ML, et al. Protein intake and incident frailty in the Women's Health Initiative observational study. J Am Geriatr Soc 2010;58:106371.

55. Morley JE. Developing novel therapeutic approaches to frailty. Curr Pharm Des 2009; 15:3384-95.

56. Morley JE, Haren MT, Rolland Y, Kim MJ. Frailty. Med Clin North Am 2006;90:837-47.1

57. Artz AS. Anemia and the frail elderly. Semin Hematol 2008;45:261-6.

58. Bilotta C, Case A, Nicolini P, Mauri S, Castelli M, Vergani C. Social vulnerability, mental health and correlates of frailty in older outpatients living alone in the community in Italy. Aging Ment Health 2010;14:1024-36.

59. Park-Lee E, Fredman L, Hochberg M, Faulkner K. Positive affect and incidence of frailty in elderly women caregivers and noncaregivers: Results of Caregiver-Study of Osteoporotic Fractures. J Am Geriatr Soc 2009;57:627-33. 


\section{FRAILTY: DIAGNOSIS AND MANAGEMENT}

60. Raji MA, Al Snih S, Ostir GV, Markides KS, Ottenbacher KJ. Cognitive status and future risk of frailty in older Mexican Americans. J Gerontol A Biol Sci Med Sci 2010;65:1228-34

61. Boyle PA, Buchman AS, Wilson RS, Leurgans SE, Bennett DA. Physical frailty is associated with incident mild cognitive impairment in community-based older persons. J Am Geriatr Soc 2010;58:248-55.

62. Avila-Funes JA, Amieva H, Barberger-Gateau P, Legoff M, Raoux N, Ritchie K. Carriere I, Tavernier B, Tzourio C, Gutierrez-Robledo LM, Dartigues JF. Cognitive impairment improves the predictive validity of the phenotype of frailty for adverse health outcomes: The Three-City Study. J Am Geriatr Soc 2009;57:452-61.

63. Semba RD, Blaum CS, Bartali B, et al. Denture use, malnutrition, frailty, and mortality among older women living in the community. J Nutr Health Aging 2006;10:161-7.

64. Matteini AM, Walston JD, Bandeen-Roche K, et al. Transcobalamin-II variants, decreased vitamin B12 availability and increased risk of frailty. J Nutr Health Aging 2010;14:73-77.

65. Fiatarone MA, O'Neill EF, Ryan ND, Clements KM, Solares GR, Nelson ME, Roberts SB, Kehayias JJ, Lipsitz LA, Evans WJ. N Engl J Med 1994;330:1769-75.

66. Theou O, Stathokostas L, Roland KP, Jakobi JM, Patterson C. Vandervoort AA, Jones GR. The effectiveness of exercise interventions for the management of frailty: A systematic review. J Aging Res 2011;2011:569194 (abstract).

67. Rolland Y, Abellan van Kan G, Vellas. Physical activity and Alzheimer's disease: From prevention to therapeutic perspectives. J Am Med Dir Assoc 2008;9:390-405.

68. Wengstrom Y, Wahren LK, Grodzinsky E. Importance of dietary advice, nutritional supplements and compliance for maintaining body weight and body fat after hip fracture. J Nutr Health Aging 2009;13:632-8.

69. Bonnefoy M, Laville M, Ecochard R, et al. Effects of branched amino acids supplementation in malnourished elderly with catabolic status. J Nutr Health Aging 2010;14:579-84

70. Morley JE, Argiles JM, Evans WJ, et al. Society for Sarcopenia, Cachexia, and Wasting Disease. Nutritional recommendations for the management of sarcopenia. J Am Med Dir Assoc 2010;11:391-6.

71. Wilson MM, Purushothaman R, Morley JE. Effect of liquid dietary supplements on energy intake in the elderly. Am J Clin Nutr 2002:75:944-7.

72. Ensrud KE, Blackwell TL, Cauley JA, et al. Circulating 25-hydroxyvitamin D levels and frailty in older men: The osteoporotic fractures in men study. J Am Geriatr Soc 2011;59:101-6.

73. Shardell M, Hicks GE, Miller RR. Association of low vitamin D levels with the frailty syndrome in mean and women. J Gerontol A Biol Sci Med Sci 2009;64:69-75.

74. Annweiler C, Schott AM, Berrut G, Fantino B, Beauchet O. Vitamin D-related changes in physical performance: A systematic review. J Nutr Health Aging 2009;13:893-8

75. Annweiler C, Beauchet O, Berrut G, Fantino B, Bonnefoy M, Hermann FR, Schott $\mathrm{AM}$. Is there an association between serum 25-hydroxyvitamin D concentration and muscle strength among older women? Results from baseline assessment of the EPIDOS study. J Nutr Health Aging 2009; 13:90-5.

76. Mastaglia SR, Seijo M, Muzio D, Somoza J, Nunez M, Oliveri B. Effect of vitamin D nutritional status on muscle function and strength in healthy women aged over sixty-fie years. J Nutr Health Aging 2011;15:349-54.

77. Bischoff Berrari HA. Validated treatments and therapeutic perspectives regarding nutritherapy. J Nutr Health Aging 2009;13:737-41.

78. Morley JE. Vitamin D redux. J Am Med Dir Assoc 2009;10:591-2.

79. Bauer JM, Kaiser MJ, Sieber CC. Sarcopenia in nursing home residents. J Am Med Dir Assoc 2008;9:545-51.

80. Gau JT. Prevalence of vitamin D deficiency/insufficiency practice patterns in nursing homes. J Am Med Dir Assoc 2010;11:296. (one page)

81. Demontiero O, Hermann M, Duque G. Supplementation with vitamin D and calcium in long-term care residents. J Am Med Dir Assoc 2011;12:190-4.

82. Basaria S. Coviello AD, Travison TG, Storer TW, Farwell WR, Jette AM, Eder R, Tennstedt S. Ulloor J. Zhang A, Choong K. Lakshman KM, Mazer NA, Miciek R, Krasnoff J. Elmi A, Knapp PE, Brooks B, Appleman E, Aggarwal S. Bhasin G, Hede-Brierly L, Bhatia A, Collins L, LeBrasseur N, Fiore LD, Bhasin S. Adverse events associated with testosterone administration. N Engl J Med 2010;363:109-22.

83. Srinivas-Shankar U, Roberts SA, Connolly MJ, O'Connell MD, Adams JE, Oldham JA, Wu FC. Effects of testosterone on muscle strength, physical function, body composition, and quality of life in intermediate-frail and frail elderly men: A randomized, double-blind, placebo-controlled study. J Clin Endocrinol Metab 2010;95:639-50.

84. Kenny AM, Kleppinger A, Annis K, et al. Effects of transdermal testosterone on bone and muscle in older men with low bioavailable testosterone levels, low bone mass, and physical frailty. J Am Geriatr Soc 2010;58:1134-43.

85. Malkin CJ, Pugh PJ, West JN, vanBeek EJ, Jones TH, Channer KS. Testosterone therapy in men with moderate severity heart failure: A double-blind randomized placebo controlled trial. Eur Heart J 2006;27:57-64.

86. Caminiti G, Volterrani M, Lellamo F, Marazzi G, Massaro R, Miceli M, Mammi C,
Piepoli iM, Fini M, Rosano GM. Effect of long-acting testosterone treatment on functional exercise capacity, skeletal muscle performance, insulin resistance, and baroreflex sensitivity in elderly patients with chronic heart failure a double-blind, placebo-controlled, randomized study. J Am Coll Cardiol 2009;54:919-27.

87. Iellamo F, Volterrani M, Caminiti G, Karam R, Massaro R, Fini M, Collins P, Rosano GM. Testosterone therapy in women with chronic heart failure: A pilot double-blind, randomized, placebo-controlled study. J Am Coll Cardiol 2010;56:1310-6.

88. Chapman IM, Visvanathan R, Hammond AJ, Morley JE, Field JB, Tai K, Belobrajdic DP, Chen RY, Horowitz M. Effect of testosterone and a nutritional supplement, alone and in combination, on hospital admission in undernourished older men and women. Am J Clin Nutr 2009;89:880-9.

89. Haren MT, Malmstrom TK, Banks WA, Patrick P, Miller DK, Morley JE. Lower serum DHEAS levels are associated with a higher degree of physical disability and depressive symptoms in middle-aged to older African American women. Maturitas 2007;57:347-60.

90. Kenny AM, Boxer RS, Kleppinger A, et al. Dehyroepiandrosterone combined with exercise improves muscle strength and physical function in frail older women. J Am Geriatr Soc 2010;58:1707-14.

91. Chumlea WC, Cesarit M, Evans WJ, et al. Sarcopenia: designing phase IIb trials: International Working Group on Sarcopenia. J Nutr Health Aging 2011;15:450-5.

92. Dharmarajan TS, Banik P, Kanagala M, et al. High prevalence of chronic kidney disease, anemia, and falls in an urban long-term care facility: relationship or coincidence? J Am Med Dir Assoc 2010;11:297-9.

93. Schnelle J, Osterweil D, Globe D, et al. Chronic kidney disease, anemia, and the association between chronic kidney disease-related anemia and activities of daily living in older nursing home residents. J Am Med Dir Assoc 2009;10:120-6.

94. Dharmarajan TS, Widjaja D. Erythropoiesis-stimulating agents in anemia: use and misuse. J Am Med Dir Assoc 2009;10:607-16.

95. Patel M, G Thimons D, L Winston J, et al. An open-label, randomized, multicenter, controlled study of epoetin alfa for the treatment of anemia of chronic kidney disease in the long-term care setting. J Am Med Dir Assoc 2010;9(Epub ahead of print).

96. Song SN, Tomosugi N, Kawabata H, Ishikawa T, Nishikawa T, Yoshizaki K. Downregulation of hepcidin resulting from long-term treatment with an anti-IL-6 receptor antibody (tocilizumab) improves anemia of inflammation in multicentric Castleman disease. Blood 2010;116:3627-34.

97. Ellis G, Whitehead MA, O’Neill D, Langhorne P, Robinson D. Comprehensive geriatric assessment for older adults admitted to hospital. Cochrane Database Syst Rev 2011;6:CD006211.

98. Li C-M, Chen C-Y, Li C-Y et al. The effectiveness of a comprehensive geriatric assessment intervention program for frailty in community-dwelling people: a randomized, controlled trial. Arch Gerontol Geriatr 2010;50(Suppl 1):S39-S42.

99. Leveille SC, Wagner EH, Davis C, et al. Preventing disability and managing chronic illness in frail older adults: a randomized trial of a community-based partnership with primary care. J Am Geriatr Soc 1998;46:1191-1198.

100. Melis RJ, Van Eijken MI, Teerenstra S, et al. A randomized study of a multidisciplinary program to intervene on geriatric syndromes in vulnerable older people who live at home (Dutch EASYcare Study). J Gerontol A Biol Sci Med Sci 2008;63:M283-M290.

101. Fabacher D, Josephson K, Pietruszka F, et al. An in-home preventive assessment program for independent older adults: a randomized controlled trial. J Am Geriatr Soc 1994;42:630-638.

102. Morley JE. Hypertension: Is it overtreated in the elderly? J Am Med Dir Assoc 2010;11:147-52

103. Romera Ortuno R, Cogan L, Foran T, et al. Continuous noninvasive orthostatic blood pressure measurements and their relationship with orthostatic intolerance, falls, and frailty in older people. J Am Geriatr Soc 2011;59:655-65.

104. Fitzgerald SP, Bean NG. An analysis of the interactions between individual comorbidities and their treatments-implications for guidelines and polypharmacy. $\mathrm{J}$ Am Med Dir Assoc 2010;11:475-84.

105. Fitzgerald SP, Bean NG. An analysis of the interactions between individual comorbidities and their treatments-Implications for guidelines and polypharmacy. J Am Med Dir Assoc 2010;11:475-84.

106. Gokce Kutsal Y, Barak A, Atalay A, Baydar T, Kucukoglu S, Tuncer T, Hizmetli S, Dursun N, Eyigor S, Saridogan M, Bodur H, Canturk F, Turhanoglu A, Arslan S, Basaran A. Polypharmacy in the elderly: A multicenter study. J Am Med Dir Assoc 2009;10:486-90.

107. Peterson MJ, Giuliani C, Morey et al. Physical activity as a preventative factor for frailty: the health, aging, and body composition study. J Gerontol A Biol Sci Med Sci 2009;64:61-8.

108. Kang HG, Costa MD, Priplata AA, et al. Frailty and the degradation of complex balance dynamics during a dual-task protocol. J Gerontol A Biol Sci Med Sci 2009;64:1304-11. 